\title{
Susanti dkk.
}

\section{Molecular Docking Sianidin dan Peonidin Sebagai Antiinflamasi pada Aterosklerosis Secara In Silico}

\author{
Susanti, N. M. P. ${ }^{*}$, D. P. D. Saputra ${ }^{1}$, P. L. Hendrayati ${ }^{1}$, I. P. D. N. Parahyangan ${ }^{1}$, I. A. D. G. Swandari ${ }^{1}$ \\ ${ }^{1}$ Program Studi Farmasi Fakultas Matematika dan Ilmu Pengetahuan Alam Universitas Udayana, Bukit Jimbaran, \\ Badung, 80361 \\ *Penulis korespondensi:: dekpitsusanti@,unud.ac.id \\ Received June 27, 2018; Accepted July 5, 2018
}

\begin{abstract}
ABSTRAK
Aterosklerosis merupakan penyakit inflamasi kronis yang diawali oleh disfungsi endotel sehingga terjadi pertumbuhan plak pada dinding dalam arteri. Disfungsi endotel menyebabkan endotel mengaktifkan $\mathrm{NF}_{\mathrm{K}} \mathrm{B}$ sehingga terjadi proses transkripsi gen proinflamasi yang mendukung pertumbuhan plak aterosklerosis. Antosianin ubi jalar ungu merupakan senyawa yang diketahui memiliki aktivitas menghambat proses inflamasi. Antosianin mayor yang terdapat dalam ubi jalar ungu adalah sianidin dan peonidin. Dilakukan uji aktivitas sianidin dan peonidin sebagai antiinflamasi pada aterosklerosis berdasarkan interaksinya pada protein NF-кB menggunakan metode molecular docking secara in silico. Tahapan penelitian yang dilakukan adalah penyiapan database struktur protein $\mathrm{NF- \textrm {K }}$, preparasi protein menggunakan aplikasi Chimera1.10.1, preparasi dan optimasi struktur 3D sianidin dan peonidin menggunakan aplikasi HyperChem8, serta validasi metode molecular docking dan docking sianidin dan peonidin pada protein $\mathrm{NF}_{-\mathrm{k}} \mathrm{B}$ menggunakan aplikasi Autodock4.2. Hasil penelitian menunjukkan bahwa sianidin dan peonidin memiliki afinitas dan membentuk ikatan hidrogen dengan protein $\mathrm{NF- \textrm {K }}$. Energi ikatan antara sianidin dan peonidin dengan protein NF-кB berturut-turut sebesar -7,92 $\mathrm{kkal} / \mathrm{mol}$ dan $-7,86 \mathrm{kkal} / \mathrm{mol}$ yang sama-sama membentuk ikatan hidrogen dengan asam amino LEU472 pada binding site yang sama dengan native ligand. Sianidin dan peonidin memiliki potensi aktivitas sebagai antiaterosklerosis karena memiliki afinitas dengan protein $\mathrm{NF- \textrm {B }}$ sehingga mempu mencegah proses inflamasi dalam pembentukan plak aterosklerosis.
\end{abstract}

Kata Kunci : Antiaterosklerosis, sianidin, peonidin, molecular docking, in silico

\section{ABSTRACT}

Atherosclerosis is a chronic inflammatory disease that begins with endothelial dysfunction resulting in plaque growth in the inner walls of the arteries. Endothelial dysfunction causes endothelial activates $\mathrm{NF}-\mathrm{kB}$ resulting in a transcription of proinflammatory gene supporting the growth of atherosclerotic plaque. The purple sweet potato anthocyanin is a compound known to have activity inhibiting the inflammatory process. The major anthocyanins contained in purple sweetpotato are cyanidine and peonidine. The cyanidine and peonidin activity test was performed as antiinflammatory at atherosclerosis based on their interaction on $\mathrm{NF- \textrm {K }}$ protein using molecular docking method in silico. The stages of this research are preparation of protein structure database of $\mathrm{NF}_{-\mathrm{KB}} \mathrm{B}$, protein preparation using Chimera1.10.1 application, preparation and optimization of cyanidin and peonidin 3D structure using HyperChem8 application, and validation of molecular docking and docking method of cyanidin and peonidin on $\mathrm{NF}-\mathrm{kB}$ protein using application Autodock4.2. The results showed that cyanidine and peonidine had affinity and formed a hydrogen bond with the NF-KB protein. The bond energy between cyanidine and peonidine with the NF-kB protein is $-7.92 \mathrm{kcal} / \mathrm{mol}$ and $-7.86 \mathrm{kcal} / \mathrm{mol}$ which together form the hydrogen bond with the LEU472 amino acid on the binding site equal to the native ligand. Cyanidin and peonidine have the potential of activity as antiatherosklerosis because it has an affinity with the $\mathrm{NF}_{\mathrm{K}} \mathrm{B}$ protein so that it prevents the inflammatory process in the formation of atherosclerotic plaque.

Keywords: Antiaterosklerosis, cyanidine, peonidine, molecular docking, in silico 
Jurnal Farmasi Udayana, Vol 7, No.1, Tahun 2018, 28-33

\section{PENDAHULUAN}

Penyakit kardiovaskular merupakan penyakit akibat gangguan fungsi jantung dan pembuluh darah yang menyebabkan $31 \%$ atau sekitar 17,5 juta jiwa dari jumlah kematian dunia pada tahun 2012. Dari jumlah kematian tersebut, 7,4 juta disebabkan oleh penyakit jantung koroner (PJK) dan 6,7 juta oleh stroke (Kemenkes RI, 2017). PJK terjadi akibat penyempitan arteri koroner sehingga tidak ada aliran darah ke otot jantung. Hal yang mendasari terjadinya PJK adalah aterosklerosis yang merupakan inflamasi kronis pada dinding dalam arteri sehingga terjadi penebalan dan penurunan elastisitas (Srividya, 2017).

Hiperkolesterolemia kronik merupakan salah satu hal utama penyebab disfungsi endotel. Hiperkolesterolemia kronik akan menyebabkan terjadinya penimbunan LDL di daerah intima. Adanya radikal bebas akan menyebabkan teroksidasinya LDL yang disebut ox-LDL yang mampu mengaktifkan sel endotel sehingga menghasilkan sitokin proinflamasi dan molekul adhesi yang merangsang infiltrasi monosit dan limfosit $T$ ke daerah intima. (Lintong, 2009; Hansson, 2005). Sitokin akan memicu diferensiasi monosit menjadi makrofag yang akan memfagositosis ox-LDL sehingga membentuk sel busa yang berkontribusi dalam terjadinya plak aterosklerosis (Ingersoll et al., 2011; Francis and Pierce, 2011). Selain itu, sitokin proinflamasi mampu menyebabkan fosforilasi $\mathrm{I}_{\mathrm{K}} \mathrm{B}$ sehingga NF-кB terlepas dari kompleks $\mathrm{NF-kB-IкB} \mathrm{menuju} \mathrm{nukleus} \mathrm{untuk} \mathrm{mendukung}$ proses transkripsi gen proinflamasi (Ayukarningsih, 2014). Berdasarkan mekanisme terbentuknya plak tersebut, maka dilakukan penelitian guna pengembangan obat aterosklerosis salah satunya melalui mekanisme pencegahan pembentukan plak dengan penghambatan proses terjadinya infllamasi.

Antosianin merupakan senyawa yang diketahui memiliki aktivtas farmakologi sebagai antiinflamasi serta memiliki aktivitas dalam proteksi penyakit kardiovaskular. Dalam usus halus, antosianin akan dihidrolisis menjadi bentuk aglikon (antosianidin) yang lebih hidrofobik. Bentuk ini akan lebih mudah diabsorpsi secara difusi pasif dan

\section{bioavailabilitasnya akan lebih baik} dibandingkan dengan antosianin sehingga potensi efek yang dihasilkan juga semakin besar (Pojer et al., 2013; Speciale et al., 2014).

Beberapa penelitian mengenai aktivitas antiinflamasi antosianin dari ubi jalar ungu dalam menghambat proses inflamasi telah dilaporkan, dimana antosianin mayor yang terdapat dalam ubi ungu adalah sianidin dan peonidin (Lim et al., 2013). Maka dari itu, perlu dilakukan penelitian untuk mengetahui aktivitas sianidin dan peonidin sebagai antiinflamasi pada aterosklerosis berdasarkan interaksinya pada protein NF-кB menggunakan metode molecular docking secara in silico. Dengan metode ini dapat diketahui afinitas ikatan ligand uji serta interaksi yang terjadi sehingga dapat diprediksi potensi sianidin dan peonidin sebagai antiinflamasi pada aterosklerosis.

\section{BAHAN DAN METODE \\ 2.1. Bahan}

Bahan yang digunakan adalah protein NF-кB (pdb id: 4IDV) yang diunduh dari https://www.rcsb.org/ pdb/home/home.do dan struktur tiga dimensi sianidin dan peonidin dibuat dan dipreparasi menggunakan program HyperChem 8.

\subsection{Alat}

Seperangkat komputer dengan spesifikasi Windows 764 bit dan program Autodock 4.2 pada OS Windows, Chimera 1.10.1, dan HyperChem 8.

\subsection{Metode Penelitian \\ 2.3.1.Preparasi Protein NF-kB}

Preparasi protein $\mathrm{NF}_{-\mathrm{K}} \mathrm{B}$ diawali dengan memilih protein dalam bentuk aktif yang berikatan dengan native ligand. Selanjutnya protein $\mathrm{NF}_{-\mathrm{k}} \mathrm{B}$ dan native ligand dipisahkan dengan program Chimera 1.10.1 untuk menyediakan ruang (pocket/cavity) sehingga diketahui bentuk pocket dan koordinat pocket sebagai bahan docking.

\subsubsection{Validasi Metode Molecular Docking}

Validasi metode molecular docking dilakukan dengan men-docking-kan kembali native ligand pada protein target yang sudah dihilangkan native ligand-nya menggunakan 


\section{Susanti dkk.}

program Autodock 4.2. Metode dikatakan valid apabila nilai RMSD yang diperoleh $\leq 3 \AA$ sehingga dapat dilakukan docking senyawa uji dengan protein target (Jain and Nicholls., 2008). Untuk memperoleh metode yang valid, maka dilakukan pengaturan pada grid box sehingga diperoleh nilai RMSD $\leq 3 \AA$.

\subsubsection{Optimasi Struktur 3D Sianidin dan Peonidin}

Struktur tiga dimensi senyawa uji sianidin dan peonidin dibuat dan dioptimasi menggunakan program HyperChem 8. Optimasi struktur dilakukan pada struktur tiga dimensi sianidin dan peonidin dengan metode komputasi semi-empiris AM1 dan dilakukan kalkulasi dengan single point serta optimasi geometri.

\subsubsection{Docking Sianidin dan Peonidin pada Protein NF-kB}

Senyawa uji sianidin dan peonidin yang telah dioptimasi di-docking-kan dengan protein $\mathrm{NF}-\mathrm{KB}$ yang telah dihilangkan native ligand-nya menggunakan program Autodock 4.2 dengan grid box hasil validasi. Hasil analisis akan menunjukkan senyawa dengan konformasi dan energi ikatan terendah untuk berikatan dengan protein target.

\subsubsection{Analisis Data}

Analisis data dilakukan berdasarkan hasil energi ikatan yang dihasilkan dari hasil molecular docking. Nilai energi ikatan menunjukkan kekuatan ikatan antara senyawa uji dengan reseptor. Semakin rendah energi ikatan, maka semakin kuat ikatan antara senyawa dengan reseptor. Interaksi yang terjadi antara sianidin dan peonidin dengan protein $\mathrm{NF}_{-\mathrm{K}} \mathrm{B}$ dapat dilihat dari jenis ikatan yang terbentuk antara sianidin dan peonidin dengan protein target

\section{HASIL}

\subsection{Preparasi Protein NF-kB}

Protein NF-кB memiliki 4 rantai, yaitu A, B, C, dan D. Native ligand inhibitor dari protein NF-KB, yaitu 4-\{3-[2- amino-5-(2methoxyethoxy) pyrimidin-4- $y /$ - $1 \mathrm{H}-$ indol-5-yl $\}-2-$ methylbut-3-yn-2-ol (13V) terletak pada semua rantai protein $\mathrm{NF}_{-\mathrm{K}} \mathrm{B}$ dan preparasi protein NF-кB pada penelitian ini menggunakan rantai A. Struktur protein $\mathrm{NF- \kappa B}$ dan native ligand yang sudah terpisah dapat dilihat pada gambar 1.

\subsection{Validasi Metode}

Validasi metode molecular docking dilakukan dengan men-docking-kan kembali protein $\mathrm{NF}_{-\mathrm{K}} \mathrm{B}$ tanpa ligand dengan native ligand yang telah dipisahkan sebelumnya menggunakan program Autodock 4.2. Hasil dan visualisasi interaksi validasi metode molecular docking dapat dilihat pada tabel 1 dan gambar 2.
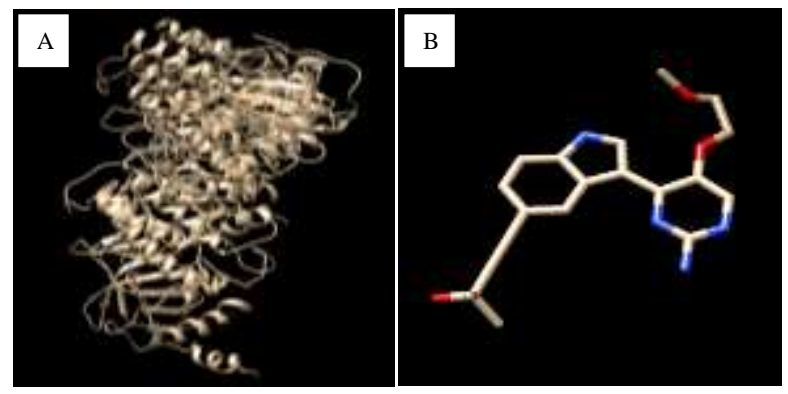

Gambar 1. Struktur Protein NF-кB (A) dan native ligand (B) yang telah terpisah dari proteinnya.

Tabel 1. Hasil Validasi Metode Molecular Docking

\begin{tabular}{lcccc}
\multicolumn{5}{c}{ Docking } \\
Ligan & $\begin{array}{c}\text { Energi } \\
\text { Ikatan } \\
(\text { Kkal/mol) }\end{array}$ & $\begin{array}{c}\text { RMSD } \\
(\AA)\end{array}$ & $\begin{array}{c}\text { Ikatan } \\
\text { Hidrogen }\end{array}$ & Gugus \\
\hline $\begin{array}{l}\text { Native } \\
\text { Ligand }\end{array}$ & $-9,84$ & 1,80 & PHE535 & $\begin{array}{c}\text { HN1- } \\
\text { O1 }\end{array}$ \\
\hline
\end{tabular}

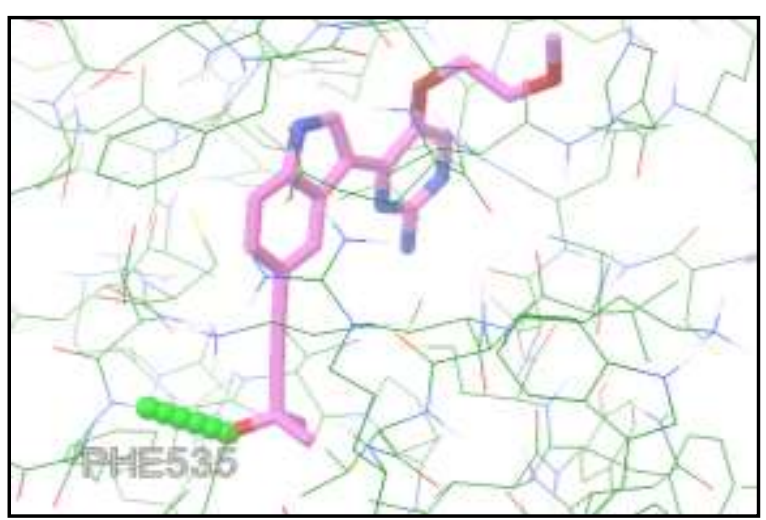

Gambar 2. Visualisasi Interaksi antara Native Ligand dengan Protein NF-KB. Interaksi berupa ikatan hidrogen ditandai dengan deretan bola berwarna hijau. Native ligand digambarkan dengan struktur berwarna ungu.

Kompleks protein digambarkan berupa struktur di sekitar native ligand. 


\section{Susanti dkk.}

\subsection{Optimasi Struktur 3D Sianidin dan Peonidin}

Struktur 3D sianidin dan peonidin digambar dan dioptimasi menggunakan program HyperChem 8. Hasil dari optimasi struktur sianidin dan peonidin ditunjukkan pada gambar 3.

\subsection{Dockinng Sianidin dan Peonidin pada Protein NF-kB}

Docking sianidin dan peonidin dilakukan menggunakan program Autodock 4.2 dengan pengaturan koordinat tempat interaksi yang sama dengan koordinat tempat interaksi native ligand pada protein NF-KB. Hasil yang diperoleh dari proses docking antara sianidin dan peonidin dengan protein $\mathrm{NF}_{-\mathrm{K}} \mathrm{B}$ berupa energi ikatan dan ikatan hidrogen yang terbentuk. Hasil dan visualisasi interaksi docking yang terjadi antara sianidin dan peonidin dengan protein NF-кB dapat dilihat pada tabel 2 dan gambar 4.

\section{PEMBAHASAN}

Preparasi protein NF-кB dilakukan dengan memisahkan protein dengan native ligand sehingga tersedia ruang (pocket/cavity) yang nantinya digunakan saat proses docking sianidin dan peonidin pada protein tersebut. Preparasi protein $\mathrm{NF}_{-\mathrm{k}} \mathrm{B}$ menggunakan rantai A yang mengandung native ligand inhibitor 4\{3-[2-amino-5-(2-methoxyethoxy) pyrimidin-4-yl]1H-indol-5-yl\}-2-metbylbut-3-yn-2-ol (13V). Hasil dari proses preparasi protein ini adalah struktur protein tanpa native ligand dan native ligand yang disimpan dalam bentuk file $\mathrm{pdb}$.

Validasi metode molecular docking dilakukan dengan men-docking-kan kembali protein $\mathrm{NF}_{-\mathrm{K}} \mathrm{B}$ tanpa ligand dengan native ligand yang telah dipisahkan sebelumnya menggunakan program Autodock 4.2. Parameter validasi metode yang digunakan adalah nilai RMSD (Root Mean Square Deviation) yang merupakan pengukuran dua pose dengan membandingkan posisi atom antara struktur eksperimental dengan struktur yang di-dockingkan pada protein (Lestari, 2015). Metode dikatakan valid apabila diperoleh nilai RMSD $\leq 3 \AA$, sehingga dari hasil validasi yang didapatkan menunjukkan bahwa metode yang

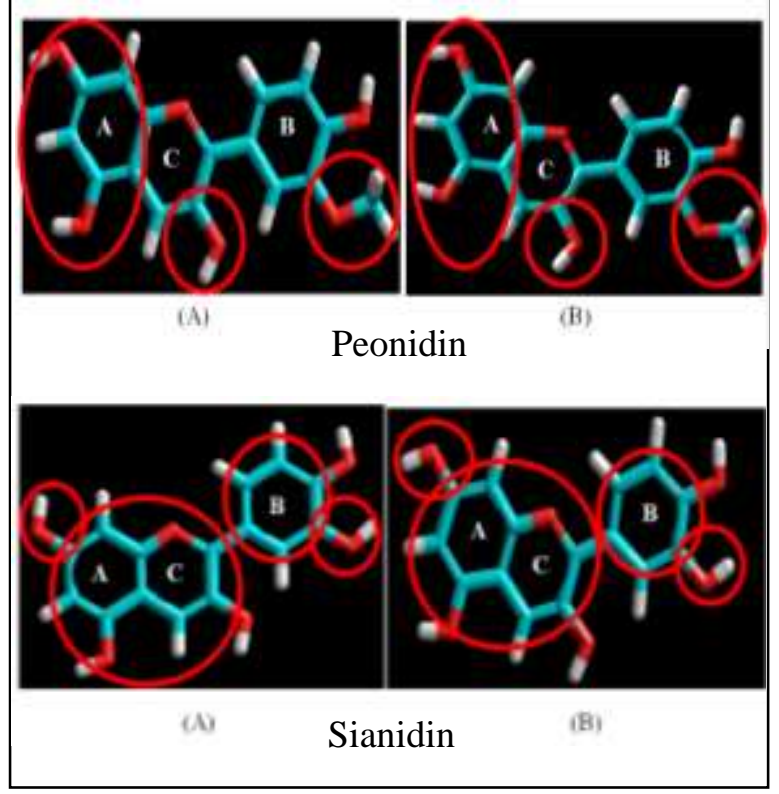

Gambar 3. Struktur 3D Sianidin dan Peonidin dengan Kalkulasi Single Point (A) dan Optimasi Geometri (B). Gugus yang mengalami pergeseran geometri ditunjukkan oleh lingkaran berwarna merah.

Tabel 2. Hasil Docking antara sianidin dan peonidin dengan protein NF-KB

\begin{tabular}{cccc}
\hline Ligan & $\begin{array}{c}\text { Energi } \\
\text { Ikatan } \\
\text { (Kkal/mol) }\end{array}$ & $\begin{array}{c}\text { Ikatan } \\
\text { Hidrogen }\end{array}$ & Gugus \\
\hline Sianidin & $-7,92$ & LEU472 & $\begin{array}{c}\text { HN- } \\
\text { O3 }\end{array}$ \\
\hline Peonidin & $-7,86$ & LEU472 & $\begin{array}{c}\text { HN- } \\
\text { O3 }\end{array}$ \\
\hline
\end{tabular}

digunakan telah valid (Jain and Nicholls., 2008). Semakin kecil nilai RMSD yang diperoleh menunjukkan bahwa pose ligand yang diprediksi semakin baik karena semakin mendekati konformasi native ligand (Agistia dkk., 2013).Optimasi struktur 3D sianidin dan peonidin diawali dengan menggambar struktur sianidin dan peonidin, kemudian dilanjutkan dengan kalkulasi single point untuk mengetahui energi awal dari struktur 3D sianidin dan peonidin. Energi yang diperoleh saat dilakukan kalkulasi single point sianidin sebesar $3611,698392 \mathrm{kkal} / \mathrm{mol}$ dan peonidin sebesar $3857,658802 \mathrm{kkal} / \mathrm{mol}$. Selanjutnya dilakukan optimasi geometri yang bertujuan untuk meminimalisasi energi agar diperoleh struktur sianidin dan peonidin yang paling stabil ditandai dengan penurunan nilai energi total 


\section{Susanti dkk.}

struktur 3D sianidin dan peonidin secara berturut-turut menjadi $-3653,787721 \mathrm{kkal} / \mathrm{mol}$ dan -3920,027926 kkal/mol (Fitriasari, 2008). Docking sianidin dan peonidin pada active site dari protein $\mathrm{NF}_{-\mathrm{K}} \mathrm{B}$ dilakukan menggunakan program Autodock 4.2 dengan pengaturan koordinat tempat interaksi yang sama dengan koordinat tempat interaksi native ligand pada protein tersebut. Hasil yang diperoleh dari proses docking antara sianidin dan peonidin dengan protein $\mathrm{NF}_{\mathrm{k}} \mathrm{B}$ berupa data energi ikatan dan ikatan hidrogen pada 10 konformasi terbaik. Energi ikatan menunjukkan afinitas antara sianidin dan peonidin dengan protein tersebut, semakin kecil energi ikatan yang diperoleh maka semakin stabil ikatan yang terbentuk (Laksmiani et al., 2016). Energi ikatan antara sianidin dan peonidin dengan protein NF-kB berturut-turut sebesar -7,92 $\mathrm{kkal} / \mathrm{mol}$ dan $-7,86 \mathrm{kkal} / \mathrm{mol}$ yang sama-sama membentuk ikatan hidrogen dengan asam amino LEU472.

Berdasarkan nilai energi ikatan yang diperoleh menunjukkan bahwa senyawa sianidin dan peonidin memiliki potensi aktivitas sebagai antiaterosklerosis karena memiliki afinitas dan membentuk ikatan hidrogen dengan protein $\mathrm{NF}_{-\mathrm{K}} \mathrm{B}$. Ikatan yang terjadi antara sianidin dan peonidin dengan protein $\mathrm{NF}_{-\mathrm{K}} \mathrm{B}$ mampu menghambat transkripsi gen proinflamasi dan migrasi otot polos sehingga terbentuknya plak aterosklerosis pada dinding pembuluh darah dapat dihambat.

\section{KESIMPULAN}

Sianidin dan peonidin memiliki potensi aktivitas sebagai antiaterosklerosis karena memiliki afinitas dan membentuk ikatan hidrogen dengan protein $\mathrm{NF}_{-\mathrm{K}} \mathrm{B}$ sehingga mempu mencegah proses inflamasi dalam pembentukan plak aterosklerosis secara in silico.

\section{UCAPAN TERIMAKASIH}

Penulis mengucapkan terimakasih kepada semua pihak yang telah membantu penelitian ini.

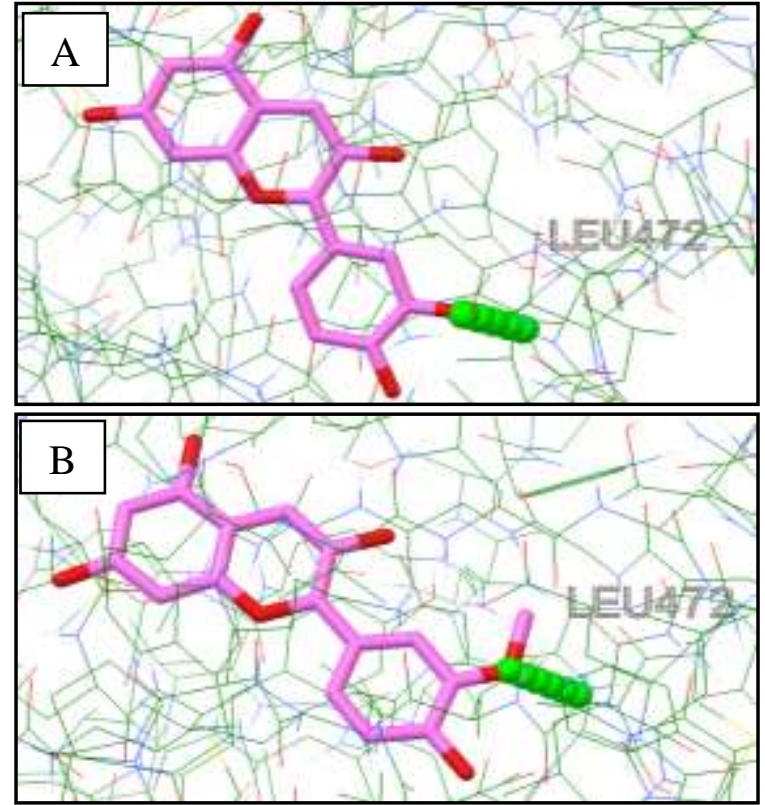

Gambar 4. Visualisasi Interaksi antara protein $\mathrm{NF}_{\mathrm{K}} \mathrm{B}$ dengan sianidin (A) dan peonidin (B). Interaksi berupa ikatan hidrogen ditandai dengan deretan bola berwarna hijau. Sianidin dan peonidin digambarkan dengan struktur berwarna ungu. Kompleks protein digambarkan berupa struktur di sekitar sianidin dan peonidin.

\section{DAFTAR PUSTAKA}

Agistia, D. D., H. Purnomo, M. Tegar, A. E. Nugroho. 2013. Interaksi Senyawa Aktif dari Aegle marmelos Correa sebagai Anti Inflamasi dengan Reseptor COX1 dan COX-2. Traditional Medicine Journal. Vol.18:80-87

Ayukarningsih, Y. 2014. Efek $\alpha$-Mangostin terhadap Aktivitas NF-кB, dan Kaspase-3 Enterosit pada Bayi Tikus Model Enterokolitis Nekrotikans. International Journal of Agriculture System. Vol.4:162-168

Fitriasari, A., N. K. Wijayanti, N. Ismiyati, D. Dewi. W. Kundarto, B. S. A. Sudarmanto, dan E. Meiyanto. 2008. Studi Potensi Kurkumin dan Analognya sebagai Selective Estrogen Receptor Modulator (SERMs): Docking pada Reseptor Estrogen $\beta$. Pharmacon. Vol.9:27-32 


\section{Susanti dkk.}

Francis, A. A. and G. N. Pierce. 2011. An Integrated Approach dor The Mecanism Responsible for Atherosclerotic Plaque Regression. Experimental and Clinical Cardiology. Vol.16:77-86

Ingersoll, M. A., A. M. Platt, S. Potteaux, and G. J. Randolph. 2011. Monocyte Trafficking in Acute and Chronic Inflammation. Trends in Immunology. Vol.32:470-477

Jain, A. N. and A. Nicholls. 2008. Recommendation for Evaluation of Computational Methods. Journal of Computer-Aided Molecular Design. Vol.22:133-139.

Kemenkes RI. 2017. Penyakit Jantung Penyebab Kematian Tertinggi, Kemenkes Ingatkan Cerdik. Available at http://www.depkes. go.id/pdf.php?id=17073100005 (Diakses pada 25 Juni 2018).

Laksmiani, N. P. L., N. L. P. V. Paramita, and I. M. A. G. Wirasuta. 2016. In Vitro and In Silico Antioxidant Activity of Purified Fractions from Purple Sweet Potato Ethanolic Extract. International Journal of Pharmacy and Pharmaceutical Sciences. Vol.8:177-181

Lestari, T. 2015. Studi Interaksi Senyawa Turunan 1,3-Dibenzoiltiourea sebagai
Ribonukleotida Reduktase Inbibitor. Jurnal Farmasi Indonesia. Vol.7:163-169

Lim, S., J. Xu, J. Kim, T. Chen, X. Su. J. Standard, E. Carey, J. Griffin, B. Herndon, B. Katz, J. Tomich, and W. Wang. 2013. Role of Anthocyaninenriched Purple-fleshed Sweet Potato P40 in Colorectal Cancer Prevention. Molecular Nutrition and Food Research. Vol. 57:1908-1917.

Lintong, P. M. 2009. Perkembangan Konsep Patogenesis Aterosklerosis. Jurnal Biomedik. Vol.1:12-22

Pojer, E., F. Mattizi, D. Johnson, and C. S. Stockley. 2013. The Case for Anthocyanin Consumption to Promote Human Health: A Review. Comprehensive Reviews in Food Science and Food Safety. Vol.12:483-508

Speciale, A., F. Cimino, A. Saija, R. Canali, and F. Virgili. 2014. Bioavailability and Molecular Activities of Anthocyanins as Modulators of Endothelial Function. Genes and Nutrition. Vol.9:1-19

Srividya. 2017. Atherosclerosis-Coronary Heart Disease and The Recent Advancements in The Treatment of Aterosclerosis. Journal of Medical and Health Sciences. Vol. 6:1-9 